\title{
Thermal adaptation and physiological responses to environmental stress in tunicates
}

\author{
V. Montalto ${ }^{1, *}$, R. Bagarella ${ }^{2}$, A. Rinaldi ${ }^{1,2}$, G. Sarà ${ }^{2}$, S. Mirto ${ }^{1}$ \\ ${ }^{1}$ Istituto per l'Ambiente Marino Costiero-Consiglio Nazionale delle Ricerche (IAMC-CNR), via G. da Verrazzano 17 , \\ 91014 Castellammare del Golfo, TP, Italy \\ ${ }^{2}$ Dipartimento di Scienze della Terra e del Mare, Viale delle Scienze Ed. 16, Università di Palermo, 90128 Palermo, Italy
}

\begin{abstract}
Understanding the multifaceted nature of environmental fluctuations is crucial to predicting the physiological adjustments utilised by organisms in resisting or adapting to changes over time. Here we investigate the effects of 2 environmental stressors on tunicates, whose fitness can have important repercussions on the quality of habitat. Specifically, we report respiration rate $(\mathrm{RR})$, clearance rate (CR), and assimilation efficiency (AE) of the ascidian Styela plicata in response to a range of temperatures and varying food availability. Temperature-dependent RR was observed only within a portion of the thermal window of the species. Significant differences in clearance rates were detected among organisms fed with varying algal concentrations, while no significant influence of food concentrations on AE was observed. This plasticity of the physiological rates and the development of ubiquitous mechanisms such as temperature-insensitive aerobic metabolism suggest a competitive advantage of this group. Such knowledge may allow for more accurate predictions of the physiological and evolutionary mechanisms driving current and future distribution of this species.
\end{abstract}

KEY WORDS: Clearance rate $\cdot$ Ecophysiology $\cdot$ Thermal tolerance $\cdot$ Trade-off

\section{INTRODUCTION}

Many biological studies focus on integrating physiological mechanisms such as metabolic performances and thermal tolerances within a broader ecological context. This is typically undertaken to improve the accuracy of predictions regarding the impact of environmental changes on the organism in question (Calosi et al. 2016). However, such research is too often based on broad-scale trends, thereby flattening both microhabitat complexity and the capacity of the organisms to buffer their responses (Helmuth et al. 2014).

Indeed, different species may show highly variable response times (Kingsolver \& Woods 2016). Therefore, understanding the variety of strategies adopted by a species might allow for a better comprehension of the complex mechanisms involved in determining

${ }^{*}$ Corresponding author: montaltovaleria@gmail.com their sensitivity to climatic change (Magozzi \& Calosi 2015) and their response to climate-related stressors (Pörtner 2010, Helmuth et al. 2014).

These aspects are particularly crucial when considering benthic sessile species, which are generally more vulnerable to the effects of climate change. This is largely due to their reduced motility, which does not allow them to alter their position in response to changing environmental conditions. To date, relatively little is known about which adaptation strategies organisms select to store energy and why particular responses to stressors remain similar in taxa which occur in habitats across a range of temperatures (Knight 2011, Marshall et al. 2011).

To address this issue, the present study explores the influence of 2 important stressors in shaping the ecological performance of tunicates, using the solitarian ascidian Styela plicata (Lesueur, 1823) as a model spe-

() The authors 2017. Open Access under Creative Commons by Attribution Licence. Use, distribution and reproduction are unrestricted. Authors and original publication must be credited. 
cies. S. plicata is a eurythermal species, widely distributed in tropical and warm-temperate marine and brackish waters (Thiyagarajan \& Qian 2003). The species is believed to have originated from the northwestern Pacific. It is a suspension feeder, capturing particles from the water which are then transported on a mucus net present across the branchial basket (Riisgard \& Larsen 2010). S. plicata benefits from the complex folding of its gill in that its physical size is reduced and it has a greater capacity for water filtration then other ascidians (e.g. Draughon 2010). The minimum size limitation for particulate removal by $S$. plicata is sufficiently small to trap both bacterial and phytoplankton communities (range 0.6 to $20 \mu \mathrm{m}$; e.g. Flood \& Fiala-Medioni 1981). Although maximum size limits have not been established, glass beads with diameter ranging between 0.5 and $2 \mathrm{~mm}$ can be retained by $S$. plicata, suggesting that it may also affect the ichthyofaunal community by removing sperm, eggs or embryos (Draughon 2010).

The Ascidiacea are important because of their unique evolutionary position. Indeed, genomic evidence has recently placed tunicates as the closest link between chordates and ancestral non-chordate deuterostomes (Delsuc et al. 2006). Moreover, their morphology and functional diversity make ascidians good candidates for invading new areas. As such, this includes the potential for negative impacts in the form of physical, ecological, and economic damage (Aldred \& Clare 2014). Regardless of the studied species, however, understanding how critical biological processes change under fluctuating environmental conditions is crucial. Responses can include alterations in the consumer's food intake, assimilation, and metabolic maintenance. Such information can be used to predict how much energy is assimilated and assigned to different needs (growth, development, and reproduction) so that the organisms can resist or adapt to environmental changes in particular habitats (Helmuth et al. 2014).

The aim of the present study was to investigate the ability of $S$. plicata to cope with variations in food availability and environmental temperatures. These parameters were examined separately to test the species' adaptive capability to colonise different habitats and to perform ecosystem functions such as maintenance of water quality.

\section{MATERIALS AND METHODS}

Throughout April and May 2015, about 500 individuals of the sea squirt Styela plicata were collected from Cala $\left(38^{\circ} 12^{\prime} 42^{\prime \prime} \mathrm{N}, 13^{\circ} 37^{\prime} 20^{\prime \prime} \mathrm{E}\right)$, a harbour area located within the Gulf of Palermo (Sicily, Italy). This species colonises most of the mooring lines at the study site located at depths of 1 to $3 \mathrm{~m}$. Animals ranging between 3 and $7 \mathrm{~cm}$ in length and between 7 and $40 \mathrm{~g}$ in wet mass were selected and transferred to the laboratory within $1 \mathrm{~h}$, where they were immediately cleaned of any epibionts by means of a scalpel and placed in a container filled with local seawater for at least $2 \mathrm{~h}$. To minimise any physiological disturbance caused by collection and by floating at the surface of the water, individuals were fixed with acrylic glue to the external side of a $65 \mathrm{~mm}$ plastic Petri dish, previously drilled. No mortality occurred during this procedure. Subsequently, animals were maintained for $2 \mathrm{~d}$ in $60 \mathrm{l}$ aquaria in aerated and filtered $(0.45 \mu \mathrm{m})$ seawater at the temperature recorded during sampling (hourly water temperature from 15 to $17^{\circ} \mathrm{C}_{\text {; }}$ www.mareografico.it). During this acclimation period, salinity was monitored and tunicates fed with the microalgae Isochrysis galbana twice daily. Prior to starting the physiological measurements, the animals were starved for at least $24 \mathrm{~h}$. The above laboratory procedures were designed to evaluate the physiological performance of individual $S$. plicata in terms of respiration rate $\left(R R, \mu m o l ~ h^{-1}\right)$ at varying temperatures and feeding behaviour.

$\mathrm{RR}$ was measured for each individual for $1 \mathrm{~h}$. Eight different replicates were used for each temperature level. Single individuals were placed in glass respirometric chambers $(500 \mathrm{ml})$ containing filtered air-saturated seawater. Temperatures were kept stable by means of a thermal bath and monitored throughout the recording period. Magnetic stirrer bars ensured water mixing within the chambers, while oxygen reduction was measured by means of 2 optical oxygen meters (Pyro Science Firesting O2). The latter enabled us to simultaneously monitor 8 different chambers for each experimental temperature through the use of specific software (Pyro Science). To evaluate the thermal tolerance of $S$. plicata, RR was measured at 17 different temperature levels $(6,8,10,12$, $15,18,21,24,27,29,31,33,35,37,39,40$, and $41^{\circ} \mathrm{C}$ ). Starting from the water acclimation temperature, the temperature in each group was increased/decreased to the next level at a rate of $1^{\circ} \mathrm{C}$ per hour (e.g. Fusi et al. 2015).

Clearance rates $\left(\mathrm{CR}, \mathrm{l} \mathrm{h}^{-1}\right)$, measured as the volume of water cleared of algal cells per hour, were determined using a static system (Widdows \& Staff 2006). The decrease in algal cell density in each experimental beaker was monitored after a given time interval. Feeding and assimilation rates were determined for 
8 different food concentrations $(0.3,0.6,1.4,2.2,3.1$, $4.4,8.6$, and $15.8 \mu \mathrm{g}^{-1} \mathrm{chl}$ a), using 10 different animals in each treatment.

Specifically, after about 30 min to allow the organism to recover from manipulation, aliquots of the algal culture (I. galbana) were added to each beaker. Then, $20 \mathrm{ml}$ subsamples were collected every $30 \mathrm{~min}$ for $2 \mathrm{~h}$ and the cell density measured using a $\mathrm{Z} 2$ Coulter Counter (Beckman Coulter) fitted with a $100 \mu \mathrm{m}$ orifice tube. CR was calculated as $\mathrm{Vol} \times(C 1-$ $C 2)$ / time, where $\mathrm{Vol}$ is the volume of water, and $C 1$ and $C 2$ are the mean cell concentrations at the beginning and end of each time increment (hours).

At the end of the CR measurements, specimens of S. plicata were singularly placed (i.e. 1 ind. beaker ${ }^{-1}$ ) into new 11 beakers containing filtered seawater and left undisturbed overnight to produce faeces. Accumulated faeces and food provided for each treatment replicate were collected by filtering the water from each beaker with GF/C filters, combusted and preweighed. The efficiency of food assimilation (AE) was calculated using the Conover (1966) ratio, $\mathrm{AE}=$ $(F-E) /[(1-E) F]$, where $F$ and $E$ are the ash-free dry weight (DW):DW ratio of the food ingested and faeces, respectively. The corresponding weight of the organic material combusted was obtained by drying the faeces and algal mass at $105^{\circ} \mathrm{C}$ for $24 \mathrm{~h}$. This was then weighed and ashed at $450^{\circ} \mathrm{C}$ for $4 \mathrm{~h}$ before being weighed a second time. Finally, 3 other replicates of every food treatment were filtered onto GF/F filters and used to quantify the concentration of chlorophyll a ( $\mathrm{chl}$ a), which served as a descriptor of species feeding. Spectrophotometric analyses of chl a were carried out according to Lorenzen \& Jeffrey (1980) by extracting pigments using 90\% acetone $\left(24 \mathrm{~h}\right.$ in the dark at $\left.4^{\circ} \mathrm{C}\right)$.

\section{Statistical analysis}

Differences in metabolic rates and feeding responses under the varying experimental conditions were tested separately (i.e. without any combinations of both factors) and were analysed by means of ANOVA (Underwood 1997). Temperature (17 levels) and food concentration (8 levels) were considered fixed factors, using 8 specimens for temperature levels and 10 specimens for food concentrations, and treated as replicates. The assumption of homogeneity of variance was tested a priori by means of the Cochran's test. The Student-Newman-Keuls (SNK) test allowed the appropriate means comparison (Underwood 1997). When no homogeneous vari- ances were rendered for any type of transformation, as in the case of $\mathrm{AE}$, the significance level was set at 0.01 instead of 0.05 . This reduced the possibility of a Type I error (Ruiz et al. 2010, Sarà et al. 2013). ANOVA was carried out using the GMAV software (version 5.0).

\section{RESULTS AND DISCUSSION}

Across the temperature ranges between $6^{\circ} \mathrm{C}$ and $41^{\circ} \mathrm{C}$, the amount of oxygen consumed mainly varied between (mean \pm SE) $1.25 \pm 0.27 \mu \mathrm{mol} \mathrm{h}^{-1} \mathrm{~g}^{-1} \mathrm{DW}$ (estimated at $6^{\circ} \mathrm{C}$ ) and $16.49 \pm 1.85 \mu \mathrm{mol} \mathrm{h} \mathrm{h}^{-1} \mathrm{~g}^{-1} \mathrm{DW}$ (at $29^{\circ} \mathrm{C}$ ). The only exception was recorded at 40 and $41^{\circ} \mathrm{C}$, where the average metabolic rate was 2 times higher (32.99 $\left.\pm 5.17 \mu \mathrm{mol} \mathrm{h} \mathrm{h}^{-1} \mathrm{~g}^{-1} \mathrm{DW}\right)$ (Fig. 1). ANOVA revealed a significant effect of temperature on the metabolic rate of Styela plicata $(\mathrm{p}<0.001$; Table S1 in the Supplement at www.int-res.com/ articles/suppl/b026p179_supp.pdf), with significant differences recorded among the rates estimated at lower $\left(6^{\circ} \mathrm{C}\right.$ and $\left.8^{\circ} \mathrm{C}\right)$ and higher $\left(40^{\circ} \mathrm{C}\right.$ and $\left.41^{\circ} \mathrm{C}\right)$ temperatures (Table S2).

$S$. plicata is commonly found in harbours, salt marsh and marine habitats in both warm and temperate waters (the Pacific, Indian and Atlantic oceans, and the Mediterranean Sea). Thus, the width of the thermal tolerance window observed in the present study overlaps with this distributional pattern. S. pli-

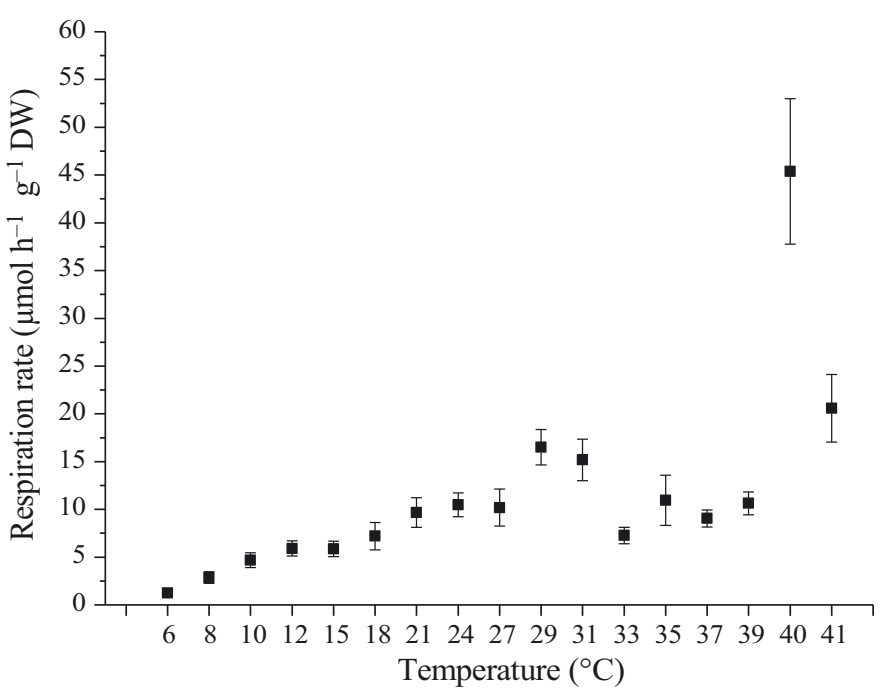

Fig. 1. Respiration rate (mean $\pm \mathrm{SE})$ of Styela plicata $(\mathrm{n}=8)$ estimated at different temperatures. The ANOVA post hoc test showed a statistically significant different effect of temperature on the metabolic rates of $S$. plicata, with significant differences (Student-Newman-Keuls test, $\mathrm{p}<0.01$ ) among rates at lower (i.e. $6^{\circ} \mathrm{C}$ and $8^{\circ} \mathrm{C}$ ) and higher $\left(40^{\circ} \mathrm{C}\right.$ and $41^{\circ} \mathrm{C}$ ) temperatures 
cata also exhibits the ability to maintain relatively low metabolic rates within a broad range of environmental temperatures. Again, the tested specimens showed an active metabolism under almost all temperatures, with thermal limits well within the range reported in the literature. The lowest temperature of metabolic functioning was $6^{\circ} \mathrm{C}$ (Fig. 1), a temperature previously reported as lethal for $S$. plicata populations within the Venice Lagoon (Sabbadin 1957). However this figure is slightly lower than the $10^{\circ} \mathrm{C}$ more recently reported as the lower boundary of its thermal range (Thiyagarajan \& Qian 2003). In our study, pairwise comparison showed that $S$. plicata remained the same at temperatures between $21^{\circ} \mathrm{C}$ and $39^{\circ} \mathrm{C}$, suggesting that metabolic maintenance made no excessive demands on the energetic tradeoff of the species. This partially confirms the observations of Fisher (1977), who suggested that a lack of larval settlement may not be a consequence of energetic deficiency due to elevated summer temperatures, but rather reflect the contribution of other different local factors. The ability to depress metabolic performance, resulting in a thermally insensitive response (sensu Verberk et al. 2016), could instead be viewed as an adaptive strategy. Thus, individuals maintain an aerobic scope to contextually cope with minor damages over a broad range of temperatures, for example, by increasing heat shock protein (HSP) activity. However prolonged exposure to stress can lead to metabolic failure in a relatively short time. In the higher temperature treatments, S. plicata individuals consumed almost all available oxygen in less than $1 \mathrm{~h}$ down to concentration of $3 \mu \mathrm{mol} \mathrm{l}^{-1}$. At this point, the aerobic scope for performance increase was progressively reduced, as represented by the plateau in the recorded metabolic rates. This response is related to the transition from the optimal to the pejus (sensu Sokolova et al. 2012) temperature range in aquatic invertebrates (Giomi \& Pörtner 2013), reflecting cascades of molecular responses activated by heat stress, and higher energetic costs. At lower temperatures tested, water oxygen concentrations decreased on average between 3.2 and $55.5 \%$ recorded at 6 and $29^{\circ} \mathrm{C}$, respectively.

Our results also confirm the considerable ability to assimilate food efficiently when resources are limited. Significant differences in mean CRs were found between individuals fed with different algal concentrations (Tables S3 \& S4, Fig. 2a). CR values lower than $1 \mathrm{l} \mathrm{h}^{-1} \mathrm{~g}^{-1} \mathrm{DW}$ were recorded at algal concentrations between (mean \pm SE) $0.3 \pm 0.03$ and $2.24 \pm$

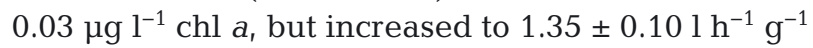
DW at concentrations higher than $3 \mu \mathrm{g} \mathrm{l}^{-1}$.
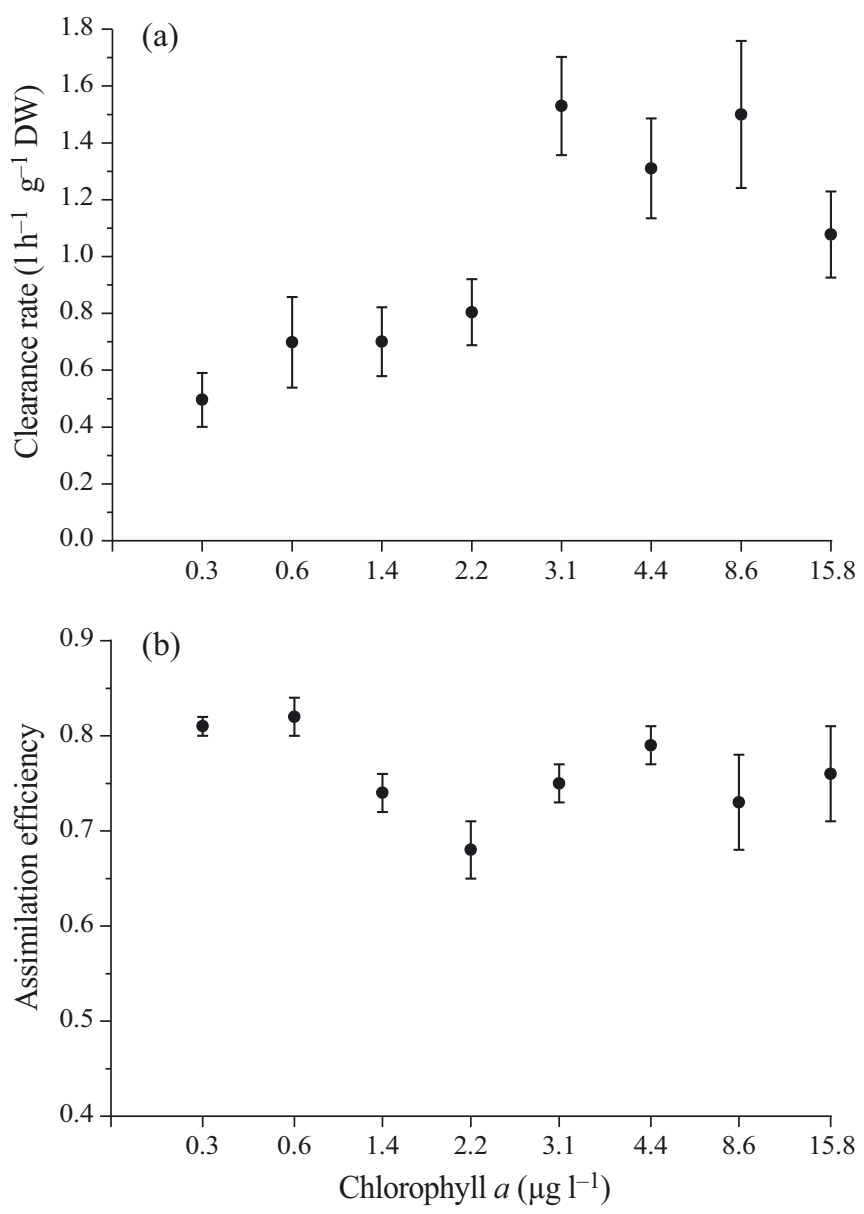

Fig. 2. Effect of food concentration on mean ( \pm SE) (a) clearance rate (CR) and (b) assimilation efficiency (AE) of Styela plicata $(\mathrm{n}=10)$. The analysis of variance showed a significant effect of food availability on CR of S. plicata $(\mathrm{p}<0.01)$, while the ANOVA post hoc test did not show statistically significant differences on AE (Student-Newman-Keuls test, $\mathrm{p}>0.05$ )

Maximum CRs (mean $\pm \mathrm{SE}$ ) of $1.53 \pm 0.17 \mathrm{l} \mathrm{h}^{-1} \mathrm{~g}^{-1}$ DW and $1.50 \pm 0.26 \mathrm{l} \mathrm{h}^{-1} \mathrm{~g}^{-1} \mathrm{DW}$ were calculated at food concentrations of 3.1 and $8.6 \mu \mathrm{g} \mathrm{l}^{-1}$, respectively. These figures are comparable with those of Draughon (2010), who reported an average CR of $1.66 \mathrm{l} \mathrm{h}^{-1} \mathrm{~g}^{-1}$ DW for $S$. plicata fed with Nannochloropsis, a microalgae similar in cell size ( 2 to $4 \mu \mathrm{m}$ ) to that used here (Isochrysis galbana, 2 to $5 \mu \mathrm{m}$ ). The variation in CR estimates between the studies may reflect the difference in the size of the organisms used to carry out the feeding experiments. Those employed in the present study were smaller than those collected by Draughon (2010), where wet weights ranged between 20 and $50 \mathrm{~g}$. The tendency of CR to increase even when resources are scarce (e.g. oligotrophic waters with $<1 \mu \mathrm{g} \mathrm{l}^{-1} \mathrm{chl} \mathrm{a}$ ) confirms that ascidians have adapted to environments with low concentrations of particles. 
However, a constant ingestion rate was recorded over a certain threshold, probably as a result of gut satiation (Petersen et al. 1999). In other words, the ingestion rate of $S$. plicata at most food densities is described by the Holling (1959) Type II functional response. Over the threshold of $8.6 \mu \mathrm{g} \mathrm{l}^{-1}$, specimens decreased their filtration rate by increasing satiation in a strictly monotonic manner (Jeschke et al. 2004). The food threshold detected in the present study is also in line with concentrations reported in previous studies (8 to12 $\mathrm{ug}^{-1} \mathrm{chl}$ a; Petersen \& Riisgard 1992).

In contrast, food concentrations did not affect the efficiency with which $S$. plicata assimilated the organic material; no significant differences were detected between treatments (Table S3). The average $\mathrm{AE}$ value was (mean $\pm \mathrm{SE}$ ) $76 \pm 10 \%$ (Fig. 2b), ranging between $0.68 \pm 0.03 \%$ and $0.82 \pm 0.01 \%$ at intermediate and low food densities, respectively. These results confirm the great ability of this group to retain microalgal cells (particle sizes ranging between 1 and $7 \mu m_{i}$ Randlov \& Riisgard 1979) and to not differentiate between the removal of inert, inorganic, and organic particles (Draughon 2010). Such efficient feeding strategy management also suggests that this species has potential to be used as a biological filter in an aquatic environment. In addition to reducing bacterial and microalgal blooms in estuarine waters (e.g. Draughon 2010), ascidian species such as S. plicata and Ciona intestinalis can also act as hosts to several different types of organisms, and serve as sentinel organisms in the bioremediation of heavy metals (Abdul Jaffar Ali et al. 2015).

In conclusion, $S$. plicata are able to efficiently manage their own metabolic trade-off. This species' ecophysiological performance may thus underpin its successful colonization of new areas with different environmental characteristics (Bates et al. 2013). In addition, it may also provide evidence of the evolution of temperature-insensitive metabolisms to save energy across part of the thermal window (Marshall et al. 2013). Maintaining elevated retention efficiency and constancy of metabolic costs within a wide range of temperatures may reduce the risk of mortality when an organism's metabolic demand (which is temperature-dependent) cannot be met by supply. Furthermore, this may also contextually confer a competitive advantage for this introduced (sensu Clarke-Murray et al. 2012) species, which is capable of causing extreme modification of the structure of coastal habitats (e.g. Sutherland 1978). Thus, S. plicata's life history traits (e.g. fast growth and hermaphroditic reproduction), lower resting maintenance costs and ecophysiological features such as a wide range in diet, likely explain its spread and establishment into new areas. Understanding the mechanisms of thermal adaptation and response to stressors in $S$. plicata will help improve predictions of physiological and evolutionary mechanisms driving current and future distributions of this species (Woodin et al. 2013).

Acknowledgements. Proof Reading Service edited the English of an earlier version of this manuscript. This study was supported by the INNOVAQUA project financed by the National Operative Programme (PON) for Research \& Competitiveness 2007-2013 (PON02_000451_3362185/1), by the Flagship Project RITMARE (Italian research for the sea), coordinated by the Italian National Research Council within the National Research Program 2011-2015, and by PRIN TETRIS 2010 grant no. 2010PBMAXP_003, funded by the Italian Ministry of Research and Universities (MIUR). The authors declare that they have no competing interests.

\section{LITERATURE CITED}

Abdul Jaffar Ali H, Tamilselvi M, Soban Akram A, Kaleem Arshan MI, Sivakumar V (2015) Comparative study on bioremediation of heavy metals by solitary ascidian, Phallusia nigra, between Thoothukudi and Vizhinjam ports of India. Ecotox Environ Safe 121:93-99

Aldred N, Clare AS (2014) Mini-review: impact and dynamics of surface fouling by solitary and compound ascidians. Biofouling 30:259-270

Bates AE, McKelvie CM, Sorte CJB, Morley SA and others (2013) Geographical range, heat tolerance and invasion success in aquatic species. Proc R Soc B 280:20131958

Calosi P, De Wit P, Thor P, Dupont S (2016) Will life find a way? Evolution of marine species under global change. Evol Appl 9:1035-1042

Clarke-Murray C, Therriault TW, Martone PT (2012) Adapted for invasion? Comparing attachment, drag and dislodgment of native and nonindigenous hull fouling species. Biol Invasions 14:1651-1663

Conover RJ (1966) Assimilation of organic matter by zooplankton. Limnol Oceanogr 11:338-354

* Delsuc F, Brinkmann H, Chourrout D, Philippe H (2006) Tunicates and not cephalochordates are the closest living relatives of vertebrates. Nature 439:965-968

Draughon LD (2010) The ascidian Styela plicata as a potential bioremediator of bacterial and algal contamination of marine estuarine waters. $\mathrm{PhD}$ dissertation, The Charles E. Schmidt College of Science, Florida Atlantic University, Boca Raton, FL

* Fisher TR (1977) Metabolic maintenance costs of the suspension feeder Styela plicata. Mar Biol 41:361-369

Flood PR, Fiala-Médioni A (1981) Ultrastructure and histochemistry of the food trapping mucous film in benthic filter-feeders (Ascidians). Acta Zool 62:53-65

Fusi M, Giomi F, Babbini S, Daffonchio D, McQuaid CD, Porri F, Cannicci S (2015) Thermal specialization across large geographical scales predicts the resilience of mangrove crab populations to global warming. Oikos 124: 784-795

Giomi F, Pörtner HO (2013) A role for haemolymph oxygen capacity in heat tolerance of eurythermal crabs. Front Physiol 4:110 
Helmuth B, Russell BD, Connell SD, Dong Y and others (2014) Beyond long-term averages: making biological sense of a rapidly changing world. Clim Change Resp 1: 6-18

Holling CS (1959) Some characteristics of simple types of predation and parasitism. Can Entomol 91:385-398

Jeschke JM, Kopp M, Tollrian R (2004) Consumer-food systems: why type I functional responses are exclusive to filter feeders. Biol Rev Camb Philos Soc 79:337-349

Kingsolver JG, Woods HA (2016) Beyond thermal performance curves: modeling time-dependent effects of thermal stress on ectotherm growth rates. Am Nat 187: 283-294

Knight K (2011) Intertidal snails are thermally insensitive. J Exp Biol 214, doi:10.1242/jeb.066266

Lorenzen CJ, Jeffrey SW (1980) Determination of chlorophyll in seawater. Unesco Tech Pap Mar Sci 35. UNESCO, Paris

Magozzi S, Calosi P (2015) Integrating metabolic performance, thermal tolerance, and plasticity enables for more accurate predictions on species vulnerability to acute and chronic effects of global warming. Glob Change Biol 21:181-194

Marshall DJ, Dong Y, McQuaid CD, Williams GA (2011) Thermal adaptation in the intertidal snail Echinolittorina malaccana contradicts current theory by revealing the crucial roles of resting metabolism. J Exp Biol 214: 3649-3657

Marshall DJ, Baharuddin N, McQuaid CD (2013) Behaviour moderates climate warming vulnerability in high-rockyshore snails: interactions of habitat use, energy consumption and environmental temperature. Mar Biol 160: 2525-2530

Petersen JK, Riisgard HU (1992) Filtration capacity of the ascidian Ciona intestinalis and its grazing impact in a shallow fjord. Mar Ecol Prog Ser 88:9-17

Petersen JK, Mayer S, Knudsen MA (1999) Beat frequency of cilia in the branchial basket of the ascidian Ciona intestinalis in relation to temperature and algal cell concentration. Mar Biol 133:185-192

Pörtner HO (2010) Oxygen- and capacity-limitation of thermal tolerance: a matrix for integrating climate-related stressor effects in marine ecosystems. J Exp Biol 213: 881-893

Editorial responsibility: Victor Benno Meyer-Rochow, Oulu, Finland
Randlov A, Riisgard HU (1979) Efficiency of particle retention and filtration rate in four species of ascidians. Mar Ecol Prog Ser 1:55-59

* Riisgard HU, Larsen PS (2010) Particle capture mechanisms in suspension-feeding invertebrates. Mar Ecol Prog Ser 418:255-293

* Ruiz JM, Marco-Mendez C, Sanchez-Lizaso JL (2010) Remote influence of off-shore fish farm waste on Mediterranean seagrass (Posidonia oceanica) meadows. Mar Environ Res 69:118-126

Sabbadin A (1957) Il ciclo biologico di Ciona intestinalis (L.), Molgula manhattensis (de Kay) e Styela plicata (Lesueur) nella laguna veneta. Arch Oceanogr Limnol XI:1-28

Sarà G, Palmeri V, Rinaldi A, Montalto V, Helmuth B (2013) Predicting biological invasions in marine habitats through eco-physiological mechanistic models: a study case with the bivalve Brachidontes pharaonis. Divers Distrib 19:1235-1247

Sokolova IM, Frederich M, Bagwe R, Lannig G, Sukhotin AA (2012) Energy homeostasis as an integrative tool for assessing limits of environmental stress tolerance in aquatic invertebrates. Mar Environ Res 79:1-15

Sutherland JP (1978) Functional roles of Schizoporella and Styela in the fouling community at Beaufort, North Carolina. Ecology 59:257-264

*Thiyagarajan V, Qian PY (2003) Effect of temperature, salinity and delayed attachment on development of the solitary ascidian Styela plicata (Lesueur). J Exp Mar Biol Ecol 290:133-146

Underwood AJ (1997) Experiments in ecology: their logical and interpretation using analysis of variance. Cambridge University Press, Cambridge

*Verberk WCEP, Bartolini F, Marshall DJ, Pörtner HO, Terblanche JS, White CR, Giomi F (2016) Can respiratory physiology predict thermal niches? Ann NY Acad Sci 1365:73-88

Widdows J, Staff F (2006) Biological effects of contaminants: measurement of scope for growth in mussels. ICES Tech Mar Environ Sci 40. ICES, Copenhagen

*Woodin SA, Hilbish TJ, Helmuth B, Jones SJ, Wethey DS (2013) Climate change, species distribution models, and physiological performance metrics: predicting when biogeographic models are likely to fail. Ecol Evol 3: 3334-3346

Submitted: February 1, 2017; Accepted: August 21, 2017 Proofs received from author(s): October 3, 2017 